\title{
PENGARUH LEVERAGE, KOMPENSASI RUGI FISKAL \\ DAN MANAJEMEN LABA TERHADAP PENGHINDARAN PAJAK
}

\author{
Ridwan Pajriyansyah \\ Amrie Firmansyah \\ Politeknik Keuangan Negara STAN Indonesia \\ amrie@pknstan.ac.id
}

\begin{abstract}
This research is aimed to provide empirical evident about relationship between leverage, loss carry forward and earnings management on tax avoidance. Using purposive sampling this research selected 264 firms that are listed in Indonesian Stock Exchange from 2013-2015 as samples. The result of multiple regression of panel data shows that there is significant relationship between leverage and earnings management on tax avoidance. Meanwhile, loss carry forward shows no significant relationship on tax avoidance.
\end{abstract}

Keywords: leverage, loss carry forward, earnings management, tax avoidance

\section{PENDAHULUAN}

Pajak merupakan sumber penerimaan terbesar Negara Republik Indonesia. Tingkat penerimaan pajak sangat penting sebagai indikator kemandirian pembangunan suatu bangsa. Pajak merupakan salah satu sumber penerimaan negara dari dalam negeri yang paling utama untuk mendanai Anggaran Pendapatan dan Belanja Negara (APBN). Dalam APBN setiap tahunnya penerimaan dari sektor pajak memiliki bagian yang paling besar dalam penerimaan. Setiap tahun target penerimaan dari sektor perpajakan mengalami peningkatan. Dalam sepuluh tahun terakhir, target pajak mengalami peningkatan terus-menerus. Tingkat capaian penerimaan juga mengalami peningkatan kecuali pada tahun 2008-2009. Pada tahun 2008, target penerimaan yang ditetapkan pemerintah dapat dipenuhi Direktorat Jenderal Pajak (DJP). Pencapaian target pada tahun tersebut disebabkan adanya kegiatan penggalian potensi yang dilakukan DJP berupa mapping, profiling, benchmarking dan kebijakan sunset policy yang membantu peningkatan penerimaan. 
Penerimaan pajak sering kali tidak tercapai disebabkan adanya praktik penghindaran pajak (nasional.kontan.co.id). Global Financial Integrity juga mencatat aliran dana haram yang dihasilkan dari penghindaran pajak dan aktivitas ilegal di Indonesia dan dikirim ke luar negeri mencapai US\$6,6 triliun periode 20062016. Upaya penghindaran pajak dari perusahaan global juga terjadi di belahan dunia lain, seperti Uni Eropa yang memperkirakan terjadi penghindaran pajak hingga merugikan keuangan negara sebesar 1 triliun euro atau Rp 12.000 triliun di tahun 2012 (pajak.go.id). Demikian juga badan pajak Inggris, HMRC (HM Revenue and Customs), yang menangani pelaporan kasus franchisor kedai kopi asal Amerika Serikat (AS), menyatakan kerugian pada laporan keuangannya tahun 2008-2010 dan contoh lainnya adalah skandal bunga pinjaman Perusahaan Air Minum (PAM) swasta Inggris. PAM ini meminjam dari induknya di Hongkong yang mengeluarkan eurobond melalui tax havens countries di Channel Islands dan Cayman Island. Anak usaha di Inggris meminjam dari induknya lebih dari 1 milyar ponsterling ( Rp 15 triliun) dengan suku bunga 11 persen atau sekitar Rp 1,65 triliun per tahun.

Kasus penghindaran pajak di Indonesia adalah pada kasus perusahaan yang terafiliasi perusahaan di Singapura, yakni PT RNI. Dari segi permodalan PT RNI menggantungkan hidup dari hutang afiliasi. Artinya, pemilik di Singapura memberikan pinjaman kepada RNI di Indonesia. Pemiliknya tidak melakukan penanaman modal, melainkan seolah-olah seperti memberikan hutang. Dalam laporan keuangan PT RNI 2014, tercatat hutang sebesar Rp 20,4 miliar. Sementara, omzet perusahaan hanya Rp 2,178 miliar. Belum lagi ada kerugian ditahan pada laporan tahun yang sama senilai Rp 26,12 miliar (Kompas.com). Dari laporan keuangan dapat dilihat bahwa perusahaan berusaha mengurangi laba dengan membesarkan pinjaman yang nantinya bunga pembayaran dapat mengurangi pajak.

Berdasarkan kasus penghindaran pajak di luar dan dalam negeri tadi, modus yang biasa dilakukan perusahaan dalam rangka penghindaran pajak adalah:

a. menggeser biaya usaha (termasuk gaji pegawai headquarters) ke negara bertarif pajak tinggi (cost center) seperti Inggris dan mengalihkan profit ke negara bertarif pajak rendah (profit center) seperti Bermuda. Dengan demikian 
keuntungan perusahaan terlihat kecil atau menjadi rugi dan tidak perlu membayar pajak korporasi

b. berhutang atau menjual obligasi kepada afiliasi perusahaan induk dan membayar kembali cicilan dengan bunga sangat tinggi. Tingkat suku bunga tinggi ini adalah dividen terselubung ke perusahaan induk.

Dapat dilihat penghindaran pajak banyak menggunakan instrumenhutang dan memainkan biaya. Dengan mengkaji penghitungan leverage dan manajemen laba, akan diketahui bagaimana pengaruhnya terhadap penghindaran pajak. Perusahaan juga akan memperoleh kerugian jika terdapat biaya yang lebih besar dibandingkan keuntungan yang diakibatkan dari manajemen laba tersebut, dengan memperoleh kerugian perusahaan berhak untuk memperoleh kompensasi atas kerugian tersebut. Oleh karena itu dilakukan penelitian bagaimana kompensasi rugi fiskal tersebut terhadap penghindaran pajak.

Penelitian sebelumnya terkait penghindaran pajak menggunakan instrumenhutang dan memainkan biaya adalah Manzon and Plesko (2002) yang meneliti hubungan pengukuran akuntansi dan pengukuran pajak penghasilan dan mendapati bahwa pendapatan sebelum pajak dan perubahan penjualan bersih berpengaruh signifikan pada tingkat konvensional terhadap book-tax accounting differences. Penelitian Frank et. al (2009) terkait hubugan pengukuran akuntansi dan pengukuran pajak penghasilan mendapati bahwa kompensasi rugi fiskal berpengaruh signifikan terhadap aggressive tax reporting. Darmawan dan Sukharta (2014) menyelidiki pengaruh leverage terhadap penghindaran pajak dan mendapati bahwa leverage tidak berpengaruh pada penghindaran pajak. Penelitian yang dilakukan Kurniasih dan Sari (2013) menyatakan bahwa kompensasi rugi fiskal memiliki pengaruh yang signifikan terhadap penghindaran pajak, namun leverage memperoleh hasil tidak berpengaruh signifikan terhadap penghindaran pajak. Penelitian yang dilakukan Waluyo et al. (2015) menyatakan bahwa leverage berpengaruh signifikan terhadap penghindaran pajak sedangkan kompensasi rugi fiskal tidak berpengaruh signifikan terhadap penghindaran pajak. Penelitian yang dilakukan Marfu'ah (2015) menyatakan bahwa leverage memiliki pengaruh 
terhadap penghindaran pajak sedangkan kompensasi rugi fiskal tidak berpengaruh terhadap penghindaran pajak. Penelitian yang dilakukan Tania Lucy (2014) menyatakan bahwa manajemen laba berpengaruh positif namun tidak signifikan terhadap penghindaran pajak perusahaan. Terakhir penelitian yang dilakukan Tiaras dan Wijaya (2015) menyatakan bahwa manajemen laba berpengaruh signifikan terhadap penghindaran pajak.

Penelitian-penelitian terdahulu tersebut menyimpulkan bahwa terdapat perbedaan hasil antara pengaruh leverage, kompensasi rugi fiskal dan manajemen laba terhadap penghindaran pajak. Penelitian ini dilakukan untuk mengetahui hasil yang konsisten atas variabel bebas tersebut terhadap penghindaran pajak. Penelitian ini juga untuk melihat bagaimana pengaruh variabel bebas tersebut mempengaruhi penghindaran pajak di Indonesia. Oleh karena itu dilakukan pengujian kembali terhadap variabel tersebut. Dengan memperhatikan kondisi di atas, penelitian inimengangkat pertanyaan penelitian: "Pengaruh leverage, kompensasi rugi fiskal dan manajemen laba terhadap penghindaran pajak"

\section{TELAAH LITERATUR DAN PENGEMBANGAN HIPOTESIS}

\section{Teori Agensi}

Teori Agensi menyatakan hubungan kontrak antara agent (manajemen suatu usaha) dan prinsipal (pemilik usaha). Agent melakukan tugas-tugas tertentu untuk prinsipal, prinsipal mempunyai kewajiban untuk memberi imbalan pada si agent (Hendriksen dan Breda, 1992). Jensen dan Meckling (1976) menyatakan bahwa hubungan keagenan sebagai kontrak antara satu atau beberapa orang (pemberi kerja atau principal) yang mempekerjakan orang lain (agent) untuk melakukan sejumlah jasa dan memberikan wewenang dalam pengambilan keputusan. Prinsipal dan agent diasumsikan sebagai pihak-pihak yang mempunyai rasio ekonomi dan dimotivasi oleh kepentingan pribadi sehingga, walau terdapat kontrak, agent tidak akan melakukan hal yang terbaik untuk kepentingan pemilik. Informasi dalam teori agensi digunakan untuk pengambilan keputusan oleh prinsipal dan agent, serta 
untuk mengevaluasi dan membagi hasil sesuai kontrak kerja yang telah disetujui. Hal ini dapat memotivasi agent untuk berusaha seoptimal mungkin dan menyajikan laporan akuntansi sesuai dengan harapan prinsipal sehingga dapat meningkatkan kepercayaan prinsipal kepada agent.

Dalam hubungan antara agent dan prinsipal, akan timbul masalah jika terdapat informasi yang asimetri (asymmetry information). Scott (2015) menyatakan apabila beberapa pihak yang terkait dalam transaksi bisnis lebih memiliki informasi daripada pihak lainnya, maka kondisi tersebut dikatakan sebagai asimetri informasi. Asimetri informasi dapat berupa informasi yang terdistribusi dengan tidak merata di antara agent dan prinsipal, serta tidak mungkinnya prinsipal untuk mengamati secara langsung usaha yang dilakukan oleh agent. Hal ini menyebabkan agent cenderung melakukan perilaku yang tidak semestinya (disfunctional behaviour). Salah satu disfunctional behavior yang dilakukan agentadalah pemanipulasian data dalam laporan keuangan agar sesuai dengan harapan prinsipal meskipun laporan tersebut tidak menggambarkan kondisi perusahaan yang sebenarnya. Pemanipulasian data dalam laporan keuangan tersebut dapat berupa praktek manajemen laba (earning management). Manajemen laba merupakan proses yang dilakukan manajer dalam batasan general accepted accounting principles, yang sengaja mengarah pada suatu tingkatan yang diinginkan atas laba yang dilaporkan (Assih, 2000). Manajemen laba dapat terjadi ketika manajemen lebih menggunakan judgement dalam menyusun laporan keuangan serta dalam memilih transaksi-transaksi yang dapat merubah laporan keuangan (Healy dan Wahlen, 1998).

Penelitian Richardson (1998) menunjukkan adanya hubungan antara asimetri informasi dengan manajemen laba. Ketika asimetri informasi tinggi, stakeholder tidak memiliki sumber daya yang cukup, insentif, atau akses atas informasi yang relevan untuk memonitor tindakan manajer, dan hal ini memberikan kesempatan atas praktek manajemen laba. Adanya asimetri informasi akan mendorong manajer untuk menyajikan informasi yang tidak sebenarnya terutama jika informasi tersebut berkaitan dengan pengukuran kinerja manajer. 


\section{Pengembangan Hipotesis}

Leverage adalah ukuran persentase total aset perusahaan yang diperoleh dari pihak kreditur (Kieso et al, 2009:796). Mills (dalam Dunbar, 2011) berpendapat bahwa leverage mencerminkan kompleksitas transaksi keuangan perusahaan, sehingga perusahaan dengan tingkat leverage yang tinggi memiliki kemampuan yang lebih untuk menghindari pajak melalui transaksi-transaksi keuangan. Perusahaan dimungkinkan menggunakan hutang untuk memenuhi kebutuhan operasional dan investasi perusahaan. Akan tetapi, hutang akan menimbulkan beban tetap (fixed rate of return) yang disebut dengan bunga. Beban bunga yang ditanggung peusahaan dapat dimanfaatkan sebagai pengurang penghasilan kena pajak perusahaan untuk menekan beban pajaknya. Hal tersebut membawa implikasi meningkatnya penggunaan hutang oleh perusahaan. Dengan demikian, maka hipotesis dalam penelitian ini adalah :

H1: leverage berpengaruh positif signifikan terhadap penghindaran pajak.

Kompensasi rugi fiskal berdasarkan Undang-Undang No. 36 tahun 2008 Pasal 6 ayat 2 tentang pajak penghasilan, bahwa perusahaan yang telah merugi dalam satu periode akuntansi diberikan keringanan untuk membayar pajaknya. Kerugian tersebut dapat dikompensasikan selama lima tahun ke depan. Secara logika, perusahaan yang telah merugi dalam satu periode akuntansi diberikan keringanan untuk membayar pajaknya. Kerugian tersebut dapat dikompensasikan selama lima tahun ke depan dan laba perusahaan akan digunakan untuk mengurangi jumlah kompensasi kerugian tersebut. Akibatnya, selama lima tahun tersebut, perusahaan akan terhindar dari beban pajak, karena laba kena pajak akan digunakan untuk mengurangi jumlah kompensasi kerugian perusahaan. Secara alamiah, fasilitas keringanan dalam pembayaran pajak ini dimanfaatkan secara maksimal oleh perusahaan. Namun sering kali pada prakteknya, fasilitas kompensasi kerugian ini sering dimanfaatkan secara berlebihan. Bahkan dalam beberapa kasus, dapat diindikasikan sebagai ajang untuk menghindari pajak. Meskipun dari beberapa cara yang dilakukan sebagian memang masih dalam koridor peraturan yang berlaku. 
Dunbar et. al (2010) dalam penelitiannya mendapatkan hasil yang positif atas pengaruh kompensasi rugi fiskal terhadap penghindaran pajak, pada penelituan tersebut digunakan beberapa proxy penghindaran yang mendapat hasil pengaruh positif antara lain menggunakan book tax different dan positive book tax different. Kompensasi rugi fiskal dapat dimanfaatkan sebagai penghindaran pajak karena perusahaan yang mendapatkan kompensasi kerugian akan terhindar dari beban pajak yang tinggi. Dengan demikian, maka hipotesis dalam penelitian ini adalah sebagai berikut :

H2: kompensasi rugi fiskal berpengaruh positif signifikan terhadap penghindaran pajak.

Penelitian Supramono (2012) menguji manajemen laba terhadap penghindaran pajak dengan menggunakan proxy discretionary accruals perusahaan untuk manajemen laba dan mendapatkan hasil bahwa manajemen laba berpengaruh signifikan terhadap agresivitas pajak perusahaan. Frank et al. (2009) juga menemukan hubungan positif antara aggressive financial reporting dan tax reporting.

Hasil positif menunjukkan pengaruh manajemen laba berupa pengurangan labaterhadap agresivitas pajak perusahaan, dapat dijelaskan bahwa laba menjadi patokan untuk mengukur besarnya beban pajak perusahaan. Oleh karena itu, manajemen akan melaporkan laba disesuaikan dengan tujuannya yaitu menggunakan pilihan akuntansi yang mengurangi laba atau income decreasing sebagai bentuk penghindaran pajak.

Menurut Scott (2015) salah satu motivasi terjadinya manajemen laba adalah motivasi pajak. Perpajakan merupakan salah satu alasan utama mengapa perusahaan mengurangi laba yang dilaporkan melalui penggunaaan akrual. Salah satu karakteristik manajemen laba adalah meminimumkan laba (income minimation) dengan cara mengurangi laba sehingga menghasilkan laba minimum yang dilaporkan maka perusahaan dapat meminimalkan besar pajak yang harus dibayarkan kepada pemerintah. Berdasarkan keterangan yang diuraikan maka dapat 
dirumuskan hipotesis manjemen laba berpengaruh positif signifikan terhadap penghindaran pajak. Ini merupakan hipotesis tiga (H3).

\section{METODE PENELITIAN DAN PEMBAHASAN}

\section{Gambaran Umum Objek Penelitian}

Penelitian ini adalah penelitian kuantitatif yang menggunakan metode deskriptif kuantitatif untuk mengolah dan menganalisis data sehingga diperoleh kesimpulan berupa hubungan antara variabel yang diamati. Dalam penelitian ini model regresi linear berganda digunakan untuk melakukan analisis data sehingga dapat diketahui ada atau tidaknya pengaruh signifikan antara variabel independen terhadap variabel dependen dan arah hubungannya..

Pengambilan sampel dilakukan dari populasi yang ada dengan metode purposive sampling (judgement sampling) yang memilih sampel secara tidak acak dengan kriteria tertentu. Kriteria tersebut adalah sebagai berikut :

1. Perusahaan yang telah terdaftar di BEI dan menerbitkan laporan keuangan secara konsisten tahun 2013 sampai dengan 2015. Pemilihan rentang waktu ini sesuai dengan masa yang akan diuji yaitu dalam kurun waktu tiga tahun.

2. Perusahaan yang memiliki kelengkapan data keuangan untuk tahun 2011 sampai dengan 2015 yang diperlukan untuk pengukuran keseluruhan variabel.

3. Perusahaan yang menggunakan mata uang rupiah. Kriteria ini diperlukan agar pengukuran nilai mata uangnya sama.

\section{Metode Pengumpulan Data}

Penelitian ini menggunakan data sekunder. Data sekunder yang digunakan dalam penelitian ini berupa laporan keuangan perusahaan yang terdaftar di bursa efek Indonesia dari tahun 2011 s.d. 2015. Data diperoleh dengan mengunduh laporan keuangan dari laman resmi Bursa Efek Indonesia dengan alamat http://www.idx.co.id 


\section{Definisi Operasional Variabel}

\section{Variabel Dependen}

Variabel dependen dalam penelitian ini adalah penghindaran pajak. Untuk Variabel penghindaran pajak dalam penelitian ini diukur menggunakan proksi Modified Effective Tax Rate (ETR) sebagaimana Atwood et al., (2012) dan Hanlon dan Heitzman (2010), dimana tax avoidance secara luas didefinisikan sebagai pengurangan atas pajak yang seharusnya dibayarkan.

$$
\text { TaxAvoid }_{i t}=\frac{\sum_{t-2}^{t}(P T E B X \times \tau)_{i t}-\sum_{t-2}^{t} C T P_{i t}}{\sum_{t-2}^{t} P T E B X_{i t}}
$$

Dimana:

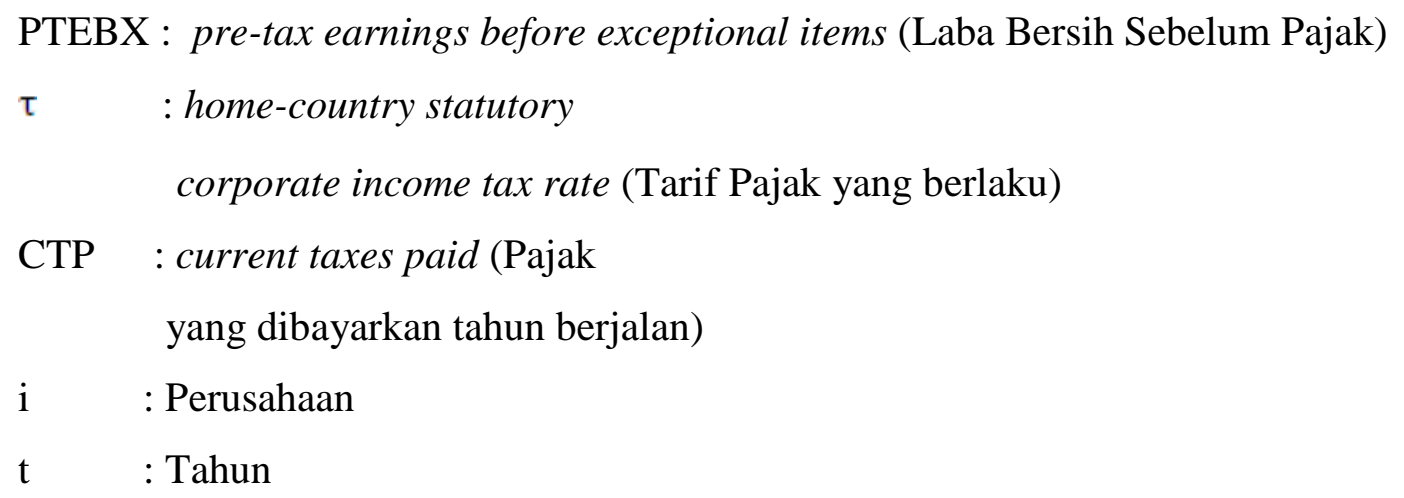

\section{Variabel Independen}

\section{Leverage}

Leverage digunakan sebagai variabel bebas dalam penelitian ini karena diperkirakan mempunyai pengaruh terhadap penghindaran pajak, dimana perusahaan dengan tingkat toleransi risiko yang tinggi kemungkinan memiliki keterlibatan penghindaran yang berbeda dengan perusahaan yang memiliki tingkat toleransi risiko yang rendah dalah rasio yang mengukur kemampuan hutang baik jangka panjang maupun jangka pendek membiayai aktiva perusahaan. Leverage diukur dengan total debt to asset ratio dengan rumus sebagai berikut:

Rasio hutang $=\frac{\text { Total Hutang }}{\text { Total Aset }}$ 


\section{Kompensasi Rugi Fiskal}

Kompensasi rugi fiskal adalah kerugian fiskal perusahaan yang dapat dikompensasikan yang hanya diperkenankan selama lima tahun kedepan secara berturut-turut. Kompensasi rugi fiskal dapat diukur dengan memberikan nilai 1 jika terdapat kompensasi rugi fiskal pada awal tahun t (Sari dan Martani, 2010).

\section{Manajemen Laba}

Model untuk mengukur manajemen laba telah banyak diteliti oleh peneliti sebelumnya. Proksi yang banyak digunakan untuk mengukur manajemen laba adalah dengan menggunakan nilai total akrual (Healy 1985; Dechow et al. 1995). Healy (1985) mengestimasikan total akrual/non discretionary acrual (NDA) dengan perbedaan diantara pendapatan akuntansi dengan arus kas dari aktivitas operasi. Healy (1985) juga berasumsi bahwa manajemen laba dilakukan dengan konstan setiap tahunnya. Berbeda dengan hal tersebut, Jones (1991) menemukan model pengukuran NDA dengan asumsi bahwa manajemen laba tidak dilakukan konstan pada setiap tahunnya.

Model Jones (1991) dimodifikasi pada penelitian-penelitian selanjutnya mulai dari Dechow et. al (1995), Kothari et. al (2005) dan Frank dan Rego (2009). Modikasi dilakukan karena model Jones tersebut gagal dalam mengestimasi porsi discretionary total accrual dan mungkin akan menyebabkan masalah yang serius dalam menarik kesimpulan. Terakhir model ini dimodifikasi Chen and EweltKnauer (2013) dengan memasukan pengungkapan pengkategorian fair value. Pengungkapan kategori penggunaan fair value seperti di Amerika Serikat baru dilakukan pada tahun 2015 di Indonesia sehingga jika model ini digunakan maka tidak sesuai dengan ruang lingkup penelitian. Oleh karena itu untuk mengukur Manajemen Laba (Earning Management) penelitian ini akan menggunakan model modified Jones(Frank \& Rego 2009) sebagai hasil residual dari persamaan total accruals (TACC). Regresi dilakukan secara crosssection pada setiap tahun dari 2013 hingga 2015. Berikut ini adalah persamaan TACC.

$$
\text { TACCit }=\alpha_{0}+\alpha_{1}(\Delta R E V i t)+\alpha_{2} P P E i t+R O A+\varepsilon i t
$$


Untuk dapat melakukan regresi maka nilai TACC harus didefinisikan terlebih dahulu. Frank and Rego (2009) nilai TACC ditentukan dengan persamaan sebagai berikut :

TACCit $=($ EBEIit + TTEit $)-[($ CFOit + ITPit $)-$ EIDOit $]$

Dengan penjelasan sebagai berikut :

TACCit $=($ Total Accruals $)$ total akrual perusahaan i pada tahun $\mathrm{t}$, yaitu selisih antara laba sebelum pos luar biasa dan operasi yang dihentikan dengan arus kas dari opersasi.

EBEIit $\quad=($ Earnings before extraordinary items from the statement of cash flow) pendapatan sebelum extraordinary item dari laporan arus kas pada perusahaan $\mathrm{i}$ tahun $\mathrm{t}$

TTEit $=($ Total tax expense $)$ total beban pajak pada perusahaan $\mathrm{i}$ tahun $\mathrm{t}$

CFOit $=($ Cash flow from operations $)$ arus kas masuk operasi pada perusahaan $\mathrm{i}$ tahun $\mathrm{t}$

ITPit $=$ (Income taxes paid from the statement of cash flow) pajak penghasilan dibayar dari laporan arus kas pada perusahaan i tahun $\mathrm{t}$

EIDOit $=$ (Extraordinary items and discontinued operations from the statement of cash Flow) extraordinary item dan discontinued operation dari laporan arus kas pada perusahaan i tahun $t$

$\triangle \mathrm{REVit} \quad=$ (Change in sales) perubahan pendapatan perusahaan $\mathrm{i}$ pada tahun $\mathrm{t}$ dengan $\mathrm{t}-1$

ROA = return on asset perusahaan i pada tahun $\mathrm{t}$ dengan $\mathrm{t}-1$

PPEit $=($ Gross property, plant, and equipment $)$ nilai kotor aset tetap perusahaan i pada tahun $\mathrm{t}$

Eit $\quad=$ (Discretionary accruals) akrual diskresioner perusahaan i pada tahun $\mathrm{t}$ 


\section{Variabel Kontrol}

\section{Return on Asset (ROA)}

Return on Assest adalah gambaran kemampuan manajemen untuk memperoleh keuntungan (laba). ROA dapat diukur dengan perbandingan antara laba bersih dengan total aset pada akhir periode, yang digunakan sebagai indikator kemampuan perusahaan dalam menghasilkan laba dengan menggunakan rumus sebagai berikut (Kurniasih \& Sari, 2013).

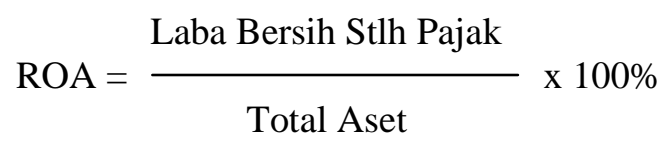

\section{Ukuran Perusahaan}

Dalam penelitian ini, ukuran perusahaan (size) didefinisikan sebagai nilai yang menggambarkan besar kecilnya ukuran suatu perusahaan. Ukuran perusahaan digunakan sebagai variabel kontrol dalam penelitian ini karena kemungkinan memiliki pengaruh signifikan terhadap hubungan dengan penghindaran pajak dimana perusahaan yang besar cenderung melakukan penghindaran pajak dibandingkan dengan perusahaan yang kecil.

Ukuran perusahaan dalam penelitian ini diukur dengan menggunakan pendekatan total aset di mana menurut Pailit $(2013,26)$ ukuran perusahaan dihitung sebagai logaritma natural dari total aset perusahaan sebagaimana banyak digunakan dalam penelitian sebelumnya. Logaritma natural digunakan pada total aset karena besarnya total asset masing-masing perusahaan berbeda-beda bahkan mempunyai selisih yang besar sehingga dapat menyebabkan nilai yang ekstrem. Untuk menghindari adanya data yang tidak normal (ekstrem) tersebut maka dalam menghitung ukuran perusahaan data total aset perlu diubah dalam logaritma natural. Dalam menghitung ukuran perusahaan digunakan rumus sebagai berikut: SIZE $=\operatorname{Ln}($ Total Asset $)$ 


\section{Model Penelitian Utama}

Variabel Dependen dalam penelitian ini adalah ukuran penghindaran pajakyang diukur berdasarkan model Modified Effective Tax Rate (ETR) (Atwood et al., 2012) yang pernah digunakan pada penelitian Hanlon dan Heitzman tahun 2010. Variabel Independen pada penelitian ini adalah financial leverage (LEV) yang diukur berdasarkan total utang dengan skala lagged asset, kompensasi rugi fiskal yang diukur dengan variabel dummy dan Manajemen Laba (TA) yang diukur dengan hasil residual dari regresi persamaan TACC. Penelitian ini menggunakan variabel kontrol ROA, dan Size.

$Y=\alpha+\beta_{1} L E V+\beta_{2} R f i s+\beta_{3} T A+\beta_{4} R O A+\beta_{5}$ Size $+\varepsilon$

Dengan penjelasan sebagai berikut :

$\mathrm{Y} \quad=$ penghindaran pajak

$\alpha \quad=$ konstanta

$\mathrm{LEV}=$ leverage

Rfis = kompensasi rugi fiskal

TA = manajemen laba

$\mathrm{ROA}=$ return on asset

Size = ukuran perusahaan

$\varepsilon \quad=$ residual

Penelitian ini menggunakan regresi data panel untuk menguji pengaruh variabel independen terhadap variabel dependen. Metode data panel digunakan karena data terdiri dari banyak observasi dan lintas waktu. Menurut Gujarati (2009) terdapat tiga metode dalam regresi data panel yaitu, metode fixed effect, random effect dan common effect. Pengujian pemilihan metode regresi data panel dilakukan untuk mendapatkan metode terbaik untuk melakukan regresi.

\section{Hasil Pemilihan Sampel}

Pemilihan sampel dalam penelitian ini berdasarkan purposive sampling dengan kriteria yang telah ditentukan sebelumnya. Kriteria pertama adalah perusahaan yang telah terdaftar di BEI dan menerbitkan laporan keuangan secara 
konsisten tahun 2013 sampai dengan 2015. Kriteria kedua adalah perusahaan yang memiliki kelengkapan data keuangan untuk tahun 2011 sampai dengan 2015 yang diperlukan untuk pengukuran keseluruhan variabel. Kriteria ketiga adalah perusahaan yang menggunakan mata uang Rupiah. Pada kriteria keempat adalah perusahaan yang bergerak di sektor manufaktur.

Tabel 4.1

Pemilihan sampel penelitian

\begin{tabular}{lc}
\hline Kriteria & Jumlah \\
\hline Perusahaan manufaktur tahun 2015 & 144 \\
Perusahaan manufaktur terdaftar di BEI 2011 & 122 \\
$\begin{array}{l}\text { Perusahaan manufaktur terdaftar di BEI yang tidak mempunyai laporan } \\
\text { keuangan lengkap tahun 2011-2015 }\end{array}$ & $(7)$ \\
Perusahaan yang menggunakan mata uang dollar pada laporan keuangan & $(27)$ \\
$\begin{array}{lc}\text { Jumlah sampel perusahaan manufaktur } \\
\text { Jumlah Observasai selama } 3 \text { tahun }(88 \times 3)\end{array}$ & 88 \\
\cline { 2 - 2 } Sun & 264
\end{tabular}

Sumber: data diolah peneliti www.idx.com

Pemilihan sampel menghasilkan 88 Perusahaan yang merupakan perusahaan yang terdaftar di BEI sejak tahun 2011 dan mempunyai laporan keuangan lengkap selama tahun 2011 sapai 2015 dan perusahaan tersebut melaporkan laporan keuangannya menggunakan mata uang rupiah. Dalam pemilihan sampel dibutuhkan data laporan keuangan dari tahun 2011 meskipun tahun observasi yang dilakukan dalampenelitian ini 3 tahun mulai dari tahun 2013-2015, karena dalam perhitungan variabel penghindaran pajak yang menggunakan proksi Modified Effective Tax Rate (ETR) (Atwood et al., 2012) membutuhkan laporan duatahun sebelumnya dari data tahun observasi.

\section{Analisis Deskriptif}

Penghindaran Pajak (Y) memiliki nilai rata-rata sebesar -0,21. Hasil tersebut menunjukkan rata-rata penghindaran pajak perusahaan manufaktur yang menjadi sampel penelitian selama periode tahun 2013 sampai 2015 mengindikasikan nilai 
rata-rata penghindaran pajak yang dilakukan perusahaan manufaktur adalah $-21 \%$ dari laba sebelum pajak.

Variabel bebas leverage yang mencerminkan dari nilai debt to asset ratio (DAR)memiliki rata rata 0,526 atau sebesar $52,6 \%$. Hal ini menunjukkan bahwa rata - rata perusahaan manufaktur yang menjadi sampel selama periode tahun 2013 hingga 2015 memiliki solvabilitas yaitu perusahaan untuk menyelesaikan segala kewajiban jangka panjangnya sebesar 52,6\%. aset yang dimilikinya dibiayai oleh hutang, baik hutang jangka panjang maupun hutang jangka pendek. Angka ini mengindikasikan juga bahwa rata rata sampel memiliki Rp 0,52 hutang untuk setiap Rp 1,00 aset yang dimiliki perusahaan.

Kompensasi rugi fiskal memiliki nilai rata rata 0,30 hal ini menunjukkan bahwa rata-rata perusahaan sampel tidak memperoleh kompensasi kerugian fiskal. Hanya sekitar 30\% dari seluruh total sampel perusahaan manufaktur dalam waktu 3 tahun 2013-2015 yang menperoleh kompensasi rugi fiskal.

Manajemen laba memiliki nilai -8,99E-18 dengan nilai tengah sebesar 0,037 Range manajemen laba adalah sebesar 3,77 dengan nilai tertinggi adalah 2,74 dan nilai terendah adalah -1,03. Angka positif menunjukkan bahwa perusahaan melakukan maksimalisasi laba sedangkan angka negatif menunjukkan perusahaan meminimalisasi laba. Secara umum perusahaan manufaktur meminimalisasi laba. Hal ini dapat dilihat dari rata-rata negatif seperti uraian dibawah.

Tabel 4.1

Analisis statistik deskriptif

\begin{tabular}{l|c|c|c|c|c|c}
\hline \hline & $\begin{array}{c}\text { Penghindaran } \\
\text { pajak }\end{array}$ & Leverage & $\begin{array}{c}\text { Kompensasi } \\
\text { rugi fiskal }\end{array}$ & $\begin{array}{c}\text { Manajemen } \\
\text { laba }\end{array}$ & $\begin{array}{c}\text { Return on } \\
\text { assets }\end{array}$ & $\begin{array}{c}\text { Ukuran } \\
\text { perusahaan }\end{array}$ \\
\hline \hline Mean & -0.211883 & 0.526109 & 0.306818 & $-8.99 \mathrm{E}-18$ & 0.050808 & 28.14413 \\
Median & -0.020063 & 0.490429 & 0.000000 & 0.003136 & 0.037946 & 27.93596 \\
Maximum & 60.37490 & 3.029099 & 1.000000 & 2.740143 & 0.401838 & 33.13405 \\
Minimum & -113.2115 & 0.037231 & 0.000000 & -1.033401 & -0.279172 & 24.31819 \\
Std. Dev. & 8.159733 & 0.410693 & 0.462049 & 0.224406 & 0.095897 & 1.659758
\end{tabular}

Sumber: Output Eviews 9 (Data Sekunder yang Diolah) 


\section{Uji Regresi Data Panel}

\section{Koefisien Determinasi}

Nilai koefisien determinasi dapat mengukur kemampuan model pada penelitian ini dapat menjelaskan variasi dari variabel dependen. Nilai koefisien determinasi ini dapat dilihat dari nilai adjusted R-squared sebesar 0,603668 menunjukkan bahwa model ini dapat menjelaskan variasi penghindaran pajak sebesar 0,603668. Sisanya sebesar 0.396332 dijelaskan oleh pengaruh lain di luar variabel yang diteliti.

Tabel 4.3.

Koefisien Determinasi.

\begin{tabular}{l|r|l|r}
\hline \hline R-squared & 0.742309 & Mean terikatt var & -0.211883 \\
Adjusted R-squared & 0.603668 & S.D. terikatt var & 8.159733 \\
S.E. of regression & 5.136952 & Akaike info criterion & 6.381057 \\
\hline \hline
\end{tabular}

Sumber: Output Eviews 9 (Data Sekunder yang Diolah)

\section{Uji signifikansi simultan (Uji-F)}

Uji F dilakukan untuk mengetahui pengaruh secara simultan variabel dalam penelitian terhadap penghindaran pajak. Tabel IV.15 memaparkan hasil Uji F menggunakan aplikasi EViews versi 9. Berdasarkan data tersebut didapatkan nilai Prob(F-statistic) sebesar 0.000000. Nilai ini berada dibawah batas signifikansi sebesar 0,05. Oleh karena itu dapat diartikan bahwa secara bersama-sama atau simultan variabel dalam penelitian ini berpengaruh signifikan terhadap penghindaran pajak.

Tabel 4.4.

Hasil Uji F

\begin{tabular}{l|r|l|r}
\hline \hline R-squared & 0.742309 & Mean terikatt var & -0.211883 \\
Adjusted R-squared & 0.603668 & S.D. terikatt var & 8.159733 \\
S.E. of regression & 5.136952 & Akaike info criterion & 6.381057 \\
F-statistic & 5.354186 & Durbin-Watson stat & 2.897280 \\
Prob(F-statistic) & 0.000000 & & \\
\hline \hline
\end{tabular}

Sumber: Output Eviews 9 (Data Sekunder yang Diolah)

\section{Uji signifikansi parsial}


Uji statistik t dalam penelitian ini digunakan untuk menunjukkan seberapa jauh pengaruh variabel bebas dalam menerangkan variasi variabel terikat. Untuk menentukan hasil uji t, dilakukan dengan melihat nilai $P>$ prob pada masing-masing variabel bebas. Jika nilainya lebih kecil dari nilai $\alpha(0,05)$ maka $H_{0}$ ditolak atau berarti variabel bebas secara parsial berpengaruh secara signifikan terhadap variabel terikat, begitu juga sebaliknya. Hasil uji t disajikan pada Tabel 4.5.

Tabel 4.5

Hasil Uji t

\begin{tabular}{|c|c|c|c|c|c|}
\hline Variabel & Coef. & Std. Error & t-statistic & $P>$ prob & signifikansi \\
\hline Lev & 21,33887 & 4,398822 & 4,851043 & 0,0000 & Signifikan \\
\hline Rfis & $-2,877119$ & 1,829495 & $-1,572630$ & 0,1177 & Tidak signifikan \\
\hline TA & 3,795055 & 1,824068 & 2,080544 & 0,0390 & Signifikan \\
\hline ROA & $-8,454028$ & 8,897667 & $-0,950140$ & 0,3434 & Tdak signifikan \\
\hline Size & $-18,23467$ & 1,648584 & $-11,06081$ & 0,0000 & Signifikan \\
\hline Cons & 503,0728 & 47,12026 & 10,67636 & 0,0000 & Signifikan \\
\hline
\end{tabular}

Sumber: Output Eviews 9 (Data Sekunder yang Diolah)

a. Pengujian pengaruh leverage terhadap penghindaran pajak

Variabel leverage memiliki nilai coefficient sebesar 21,3387 dan nilai $\mathrm{P}>$ prob sebesar 0,0000. Nilai P>prob sebesar $0,0000<$ nilai $\alpha(0,05)$. Karena pada hipotesis telah menentukan arah dari pengaruh variabel bebas terhadap variabel terikat (one-tailed) maka $p$ value diubah menjadi ( $p$ value/2) menjadi 0.0000 , artinya leverage berpengaruh secara signifikan terhadap penghindaran pajak pada level signifikansi 5\%. Arah koefisien regresi bertanda positif berarti peningkatan leverage akan menaikkan penghindaran pajak. Dengan demikian, $H 1$ yang menyatakan “leverage berpengaruh positif signifikan terhadap penghindaran pajak", diterima.

b. Pengujian pengaruh kompensasi rugi fiskalterhadap penghindaran pajak

Variabel kompensasi rugi fiskal memiliki nilai coefficient sebesar -2,877119 dan nilai $\mathrm{P}>$ prob sebesar 0,1177. Nilai $\mathrm{P}>$ prob sebesar $0,1177>$ nilai $\alpha(0,05)$. Karena pada hipotesis telah menentukan arah dari pengaruh variabel bebas terhadap variabel terikat (one-tailed) maka $p$ value diubah menjadi ( $p$ value/2) menjadi 0,05885, artinya kompensasi rugi fiskal tidak berpengaruh secara signifikan terhadap penghindaran pajak pada level signifikansi 5\%. Arah koefisien regresi bertanda negatif berarti peningkatan kompensasi rugi fiskal akan menurunkan 
penghindaran pajak. Dengan demikian, H2 yang menyatakan "kompensasi rugi fiskal berpengaruh positif signifikan terhadap penghindaran pajak", ditolak.

c. Pengujian pengaruh manajemen labaterhadap penghindaran pajak

Variabel manajemen laba memiliki nilai coefficient sebesar 3,795055 dan nilai $\mathrm{P}>$ prob sebesar 0,0390 . Nilai $\mathrm{P}>$ prob sebesar $0,0390<$ nilai $\alpha(0,05)$. Karena pada hipotesis telah menentukan arah dari pengaruh variabel bebas terhadap variabel terikat (one-tailed) maka $p$ value diubah menjadi ( $p$ value/2) menjadi 0,0195, artinya manajemen laba berpengaruh secara signifikan terhadap penghindaran pajak pada level signifikansi 5\%. Arah koefisien regresi bertanda positif berarti peningkatan manajemen laba akan menaikkan penghindaran pajak. Dengan demikian, $H 3$ yang menyatakan "manajemen laba berpengaruh positif signifikan terhadap penghindaran pajak", diterima.

\section{Leverage Terhadap Penghindaran Pajak}

Leverage yang dalam penelitian ini menggunakan total debt to asset ratio yang merupakan perbandingan antara total hutang dengan total aktiva, sehingga rasio ini menunjukkan sejauh mana hutang dapat ditutupi oleh aktiva. Menurut Sawir (2008) debt ratio merupakan ratio yang memperlihatkan proporsi antara kewajiban yang dimiliki dan seluruh kekayaan yang dimiliki. Dengan nilai leverage yang rendah, perusahaan tersebut mempunyai aktiva atau kekayaan yang cukup untuk membayar semua hutang-hutangnya begitu pula sebaliknya perusahaan dengan nilai leverage yang tinggi tidak mempunyai kekayaan yang cukup untuk membayar hutang hutangnya.

Perusahaan memilliki beberapa alternatif untuk mendapatkan dana yang diperlukan untuk menjalankan operasinya, pertama dana bisa didapatkan dari investasi yang dilakukan oleh pemilik perusahaan atau pada perusahaan terbuka bisa dengan menjual kepemilikan perusahaan berupa saham. Dana juga dapat diperoleh dengan melakukan pinjaman ke bank, lembaga non-bank maupun dari lembaga non formal. Dengan semua cara cara tersebut perusahaan akan mempunyai dana untuk menjalankan operasinya atau bahkan memperbesar usahanya, tetapi ada perbedaan 
yang cukup besar atas cara mendapatkan dana tersebut, terutama dalam perilaku akuntansi. Perusahaan yang mendapatkan dana dari investasi para pemilik perusahaan akan mencatatkan aset pada modal, sedangkan perusahaan yang mendapatkan dana dari pinjaman akan mencatatkan asset pada hutang.

Perbedaan perlakuan akuntansi tersebut yang membuat banyak perusahaan menggunakan pinjaman sebagai cara untuk mendapatkan dana atau modal. Pinjaman yang dilakukan perusahaan akan mengharuskan perusahaan melakukan pembayaran bunga atas hutang tersebut berbeda dengan pendanaan dengan investasi pemilik yang nantinya perusahaan akan memberikan deviden atas investasi tersebut. Karena hal itu banyak perusahaan lebih tertarik melakukan pinjaman untuk pendanaan mereka karena bunga hutang yang dibayarkan bisa diberlakukan sebagai biaya pengurang objek pajak penghasilan, tidak seperti deviden yang tidak bisa. Hal ini dapat menjadi salah satu cara perusahaan untuk menghindari pajak dengan mengurangi pembayaran pajak yang dibayar.

Salah satu cara berhutang yang banyak dilakukan untuk menghindar dari pajak yaitu dengan berhutang atau menjual obligasi kepada afiliasi perusahaan induk dan membayar kembali cicilan dengan bunga sangat tinggi. Mereka lebih memilih berhutang perusahaan induk atau pemilik saham daripada menerima masuknya investasi melaui pemberian modal. Dengan semakin banyak hutang maka tingkat leverage tinggi. Mills (dalam Dunbar, 2011) berpendapat bahwa leverage mencerminkan kompleksitas transaksi keuangan perusahaan. Sehingga perusahaan dengan tingkat leverage yang tinggi memiliki kemampuan yang lebih untuk menghindari pajak melalui transaksi-transaksi keuangan. Perusahaan dimungkinkan menggunakan hutang untuk memenuhi kebutuhan operasional dan investasi perusahaan. Akan tetapi, hutang akan menimbulkan beban tetap (fixed rate of return) yang disebut dengan bunga. Beban bunga yang ditanggung peusahaan dapat dimanfaatkan sebagai pengurang penghasilan kena pajak perusahaan untuk menekan beban pajaknya.

Hasil uji parsial pengaruh leverage terhadap penghindaran pajak memberikan hasil bahwa leverage berpengaruh secara signifikan terhadap 
penghindaran pajak. Hasil penelitian ini menunjukkan bahwa besar kecilnya leverage perusahaan akan mempengaruhi peningkatan maupun penurunan pada penghindaran pajak, dilihat dari nilai koefisien yang positif maka jika leverage meningkat maka akan meningkat penghindaran pajak begitu pula sebaliknya. maka dengan demikian, dapat disimpulkan bahwa hipotesis pertama yang menyatakan leverage berpengaruh signifikan terhadap penghindaran pajak, dapat diterima.

Leverage dapat mempengaruhi peningkatan dan penurunan penghindaran pajak bisa dijelaskan dengan peningkatan hutang yang dilakukan perusahaan untuk pendanaan finansialnya akan meningkatan pembayaran bunga yang akan dilakukan nanti. perusahaan memanfaatkan hutang untuk meminimalkan beban pajak perusahaan bahkan cenderung mengarah penghindaran pajak. Hal ini dikarenakan perusahaan yang memiliki hutang tinggi akan mendapatkan insentif pajak berupa potongan atas bunga pinjaman sesuai ketentuan Pasal 6 ayat (1) huruf a UU Nomor 36 tahun 2008

"Besarnya Penghasilan Kena Pajak bagi Wajib Pajak dalam negeri dan bentuk usaha tetap, ditentukan berdasarkan penghasilan bruto dikurangi biaya untuk mendapatkan, menagih, dan memelihara penghasilan, termasuk: 3. Bunga, sewa dan royalty"

Perusahaan yang memiliki beban pajak tinggi dapat melakukan penghematan pajak dengan cara menambah hutang perusahaan. Bunga pinjaman merupakan biaya yang dapat dikurangkan (deductible expense) terhadap penghasilan kena pajak. Beban bunga yang bersifat deductible akan menyebabkan laba kena pajak perusahaan menjadi berkurang. Laba kena pajak yang berkurang pada akhirnya akan mengurangi jumlah pajak yang harus dibayar perusahaan. Dengan menambah hutang guna memperoleh insentif pajak yang besar maka dapat dikatakan bahwa perusahaan tersebut agresif terhadap pajak. Mendukung penelitian Ozkan (2001) dan Choi (2003), di mana perusahaan yang memiliki beban pajak tinggi lebih banyak untuk mengajukan hutang guna mendapatkan keuntungan dari pengurangan bunga atas hutang tersebut sehingga pajak yang dibayar akan menjadi lebih kecil. Hasil penelitian ini juga sejalan dengan Mulyani (2013) yang menyatakan leverage 
berpengaruh signifikan terhadap penghindaran pajak dan Supramono (2012) dimana perusahaan manufaktur memanfaatkan hutang untuk meminimalkan beban pajak perusahaan bahkan cenderung mengarah agresif terhadap pajak dengan memanfaatkan peraturan perpajakan yang berlaku.Hasil temuan ini tidak sejalan dengan penelitian Sukartha (2014) yang menyatakan bahwa leverage tidak berpengaruh terhadap penghindaran pajak.

\section{Kompensasi Rugi Fiskal Terhadap Penghindaran Pajak}

Kompensasi rugi fiskal adalah kompensasi yang dilakukan wajib pajak atas dasar pembukuannya yang mengalami kerugian. Kerugian atau keuntungan fiskal adalah selisih antara penghasilan dan biaya-biaya yang telah memperhitungkan ketentuan Pajak Penghasilan. Kompensasi rugi fiskal ini dilakukan berdasarkan Undang-Undang No. 36 tahun 2008 Pasal 6 ayat 2 tentang pajak penghasilan yang menyebutkan "Apabila penghasilan bruto setelah pengurangan sebagaimana dimaksud pada ayat (1) didapat kerugian, kerugian tersebut dikompensasikan dengan penghasilan mulai tahun pajak berikutnya berturut-turut sampai dengan 5 (lima) tahun", maksud dari pasal tersebut bahwa perusahaan yang telah merugi dalam satu periode akuntansi diberikan keringanan untuk membayar pajaknya. Kerugian tersebut dapat dikompensasikan selama lima tahun ke depan dan laba perusahaan akan digunakan untuk mengurangi jumlah kompensasi kerugian tersebut.

Kompensasi rugi fiskal merupakan salah satu insentif perpajakan yang diberikan negara kepada wajib pajak. Insentif yang diberikan untuk memberikan rasa keadilan dalam membayar pajak. Ketika mengalami keuntungan wajib pajak akan membayar pajak dan ketika rugi negara memberikan keringanan atas pembayaran pajak dimasa yang akan datang. Insentif juga akan memberikan dorongan pada wajib pajak untuk terus mengembangkan ekonominya.Sebagai insentif fiskal, keberadaan fasilitas ini pun hanya ada dalam konteks perhitungan fiskal. Secara komersial kompensasi kerugian tidak dikenal. Jika perusahaan mengalami kerugian maka secara komersial akan berakibat pada nilai laba ditahan 
yang menjadi turun yang selanjutnya akan menurunkan nilai perusahaan tersebut. Secara fiskal, suatu perusahaan yang mengalami kerugian dalam suatu periode tahun pajak maka kerugian tersebut bisa mereka kompensasi-kan dengan keuntungan yang perusahaan tersebut peroleh di tahun-tahun berikutnya seperti yang telah dijelaskan di atas.

Secara alamiah, fasilitas keringanan dalam pembayaran pajak ini dimanfaatkan secara maksimal oleh perusahaan. Namun sering kali pada prakteknya, fasilitas kompensasi kerugian ini sering dimanfaatkan secara berlebihan. Bahkan dalam beberapa kasus, dapat diindikasikan sebagai ajang untuk menghindari pajak. Meskipun dari beberapa cara yang dilakukan sebagian memang masih dalam koridor peraturan yang berlaku. Optimalisasi umur kompensasi kerugian.

Dari penelitian ini diperoleh hasil uji parsial pengaruh kompensasi rugi fiskal terhadap penghindaran pajak bahwa kompensasi rugi fiskal tidak berpengaruh secara signifikan terhadap penghindaran pajak. Hasil penelitian ini menunjukkan bahwa besar kecilnya kompensasi rugi fiskal yang ada pada perusahaan tidak mempengaruhi peningkatan maupun penurunan pada penghindaran pajak, meskipun dalam hal ini, model regresi telah menggunakan dua variabel kontrol, yaitu return on asset dan ukuran perusahaan. Dengan demikian, dapat disimpulkan bahwa hipotesis kedua yang menyatakan kompensasi rugi fiskal berpengaruh signifikan terhadap penghindaran pajak, tidak dapat diterima.

Hasil penelitian ini sejalan dengan penelitian yang dilakukan oleh Prakosa (2014) dan Waluyo et. al (2015) yang juga menyatakan bahwa kompensasi rugi fiskal tidak mempunyai pengaruh terhadap penghindaran pajak. Akan tetapi hasil penelitian ini berbeda dengan hasil penelitian Kurniasih dan Sari (2013) dan Frank et. al (2003) yang menemukan pengaruh signifikan terhadap penghindaran pajak. Hal ini dimungkinkan karena perbedaan penggunaan sampel, waktu pengamatan, total variabel, proxy variabel maupun model regresi yang digunakan. Dalam penelitian ini, model regresi yang digunakan adalah model efek tetap terhadap 88 sampel selama tahun 2013-2015. 
Hasil penelitian menunjukkan tidak adanya pengaruh antara kompensasi rugi fiskal dengan penghindaran pajak dapat dijelaskan bahwa perusahaan dapat menghasilkan kompensasi rugi fiskal dengan mengambil keuntungan (insentif) pajak. Perusahaan yang yang telah rugi dan mempunyai nilai kompensasi rugi fiskal akan tidak terlalu mempengaruhi dalam perlakukan penghindaran pajaknya. Jika perusahaan mengambil posisi dimana perusahaan mendapatkan keuntungan sebesarbesarnya maka pajak atas penghasilan tersebut dapat dikurangkan, jika perusahaan tetap dalam posisi rugi maka nilai kompensasi rugi fiskal ini dapat digunakan dalam waktu lima tahun kedepan jadi perusahaan tidak terlalu memaksakan agar menggunakan kompensasi rugi fiskal ini secepatnya.

Dari hasil analisis diketahui bahwa rata rata kompensasi rugi fiskal perusahaan manufaktur selama 2013-2015 adalah sebesar 30\% (rata-rata perusahaan memiliki kompensasi rugi fiskal sebanyak 88 kali dari 264 data yang ada). Hal ini berarti rendahnya kompensasi rugi fiskal yang ada selama masa sampel dari 88 perusahaan tersebut. Perusahaan tidak berusaha untuk mendapatkan kompensasi rugi fiskal untuk mendapatkan keuntungan atau sebagai bagian dari penghindaran pajak, tetapi kompensasi rugi fiskal ini merupakan insentif yang didapatkan ketika perusahaan sedang mengalami kerugian. Hal ini membuktikan Ada tidaknya kompensasi rugi fiskal juga tidak akan mempengaruhi penghindaran pajak, karena apabila perusahaan memiliki kompensasi pada tahun sebelumnya perusahaan akan tetap menutupi kerugian tersebut dengan keuntungan perusahaan tahun berikutnya. Hal ini mengindikasikan bahwa ada tidaknya kompensasi rugi fiskal tidak sepenuhnya berarti bahwa perusahaan mendapat keringanan tidak membayar pajak sama sekali namun perusahaan akan tetap membayar hutang pajak apabila pada tahun berikutnya laba neto cukup dan kompensasi rugi fiskal telah digunakan seluruhnya.

\section{Manajemen Laba Terhadap Penghindaran Pajak}


Manajemen laba bisa diartikan sebagai suatu intervensi dengan maksud tertentu terhadap proses pelaporan keuangan eksternal dengan sengaja untuk memperoleh beberapa keuntungan pribadi (Schipper 1989). Menurut Scoot (2006), motivasi melakukan manajemen laba antara lain adalah bahwa indikasi praktik manajemen laba dilakukan karena tujuan bonus, motivasi kontraktual, motivasi politik, motivasi pajak, penggantian CEO, penawaran saham perdana, dan komunikasi informasi kepada investor. Melakukan manajemen laba karena motivasi pajak dilakukan agar perusahaan dapat membayar pajaknya seminimal mungkin dengan memanfaatkan adanya perbedaan antara peraturan akuntansi dengan peraturan perpajakan.

Salah satu tujuan dilakukan penelitian ini adalah untuk mengetahui pengaruh manajemen laba dengan penghindaran pajak. Manajemen laba (earnings mangement) merupakan fenomena yang sukar untuk dihindari karena fenomena ini merupakan dampak dari penggunaan dasar akrual dalam penyusunan laporan keuangan. Dalam praktek, diindikasikan bahwa para manajer melakukan tindakan tersebut tersebut untuk memaksimalkan utilitinya dan nilai pasar perusahaan maupun melakukan penghindaran pajak (Scott, 2015). Oleh karena itu dalam penelitian ini dalam menghitung penghindaran pajak menggunakan pendekatan aggregate accrual melalui model modified Jones (Frank \& Rego 2009). Salah satu kelebihan pendekatan aggregate accruals adalah pendekatan tersebut berpotensi untuk dapat mengungkap cara-cara untuk menaikkan atau menurunkan laba, karena cara-cara tersebut kurang mendapat perhatian untuk diketahui oleh pihak luar (Gumanti 2000).

Dari penelitian ini diperoleh hasil pengaruh manajemen laba terhadap penghindaran pajak bahwa manajemen laba berpengaruh secara signifikan terhadap penghindaran pajak. Hasil penelitian ini menunjukkan bahwa besar kecilnya manajemen labaperusahaan akan mempengaruhi peningkatan maupun penurunan pada penghindaran pajak, dilihat dari nilai koefisien yang positif maka jika manajemen laba meningkat maka akan meningkat penghindaran pajak begitu pula sebaliknya. maka dengan demikian, dapat disimpulkan bahwa hipotesis ketiga yang 
menyatakan manajemen laba berpengaruh signifikan terhadap penghindaran pajak, dapat diterima.

Hasil penelitian ini sejalan dengan Suyanto dan Supramono (2012) yang menyatakan bahwa manajemen laba berpengaruh positif terhadap agresivitas pajak perusahaan, dan selama periode pengamatan ada kecenderungan bahwa perusahaan melakukan income decreasing sebagai upaya penghindaran pajak. Hasil serupa juga diperoleh dari penelitian Kristanto (2015) yang menyatakan bahwa manajemen laba dengan menggunakan discretionary accrual berpengaruh positif dan signifikan terhadap penghindaran pajak dengan menggunakan Book Tax Different.

Manajemen laba memegang peranan yang sangat penting dalam praktik manajemen pajak perusahaan. Manajer perusahaan berusaha untuk mencapai laba yang diinginkan dengan selalu memperhitungkan besarnya pajak perusahaan yang harus dibayar. Oleh karena itu, maka kuat dugaan bahwa praktik manajemen laba yang dilakukan perusahaan berhubungan dengan praktik manajemen pajak perusahaan. Manajemen laba dapat mempengaruhi peningkatan dan penurunan penghindaran pajak bisa dijelaskan dengan keinginan perusahaan untuk melakukan manajemen pajak atau penghindaran pajak dalam rangka untuk membayar pajak seminimal mungkin dengan cara melakukan manajemen laba pada perusahaan. Adanya celah yang disebabkan adanya perbedaan pelaporan menurut standar akuntansi (komersial) dengan pelaporan menurut perpajakan memungkinnya dilakukan manajemen laba dengan tujuan penghindaran pajak. Perbedaan peraturan menyebabkan tujuan dan motivasi pelaporan laba fiskal dan laba komersial menjadi berbeda. Perusahaan akan menggunakan standar akuntansi yang paling optimal untuk melaporkan laba yang lebih besar. Sebaliknya, perusahaan cenderung melaporkan laba yang kecil dalam rangka meminimalkan pembayaran pajak perusahaan. Menurut Desai (2006) dalam Ayers et al. (2008), perbedaan sistem pelaporan menurut standar akuntansi dan sistem pelaporan menurut peraturan pajak (dual system) menimbulkan kreatifitas manajemen dalam membuat laporan keuangan. 
Terkait dengan perpajakan, manajer perusahaan akan melakukan pelaporan laba yang kecil agar perusahaan dapat meminimalkan pembayaran pajak perusahaan untuk meningkatkan kinerja manajemen. Manajer akan menggunakan perbedaan perlakuan perpajakan untuk mendapatkan koreksi fiskal yang dapat mengurangi laba fiskal, sehingga dapat meminimalkan kewajiban pembayaran pajak perusahaan tersebut. Dengan kewajiban pajak yang kecil maka perusahaan akan mempunyai dana yang yang dapat digunakan untuk memperluas bisnisnya.

Sementara ada beberapa hasil penelitian lain yang memiliki hasil yang berbeda, Putri (2014) menyatakan bahwa manajemen laba tidak berpengaruh signifikan terhadap agresivitas pajak perusahaan. Ini menunjukkan bahwa manajemen laba yang dilakukan perusahaan tidak berdampak besar bagi tujuan penghindaran pajak perusahaan. Manajemen laba untuk tujuan pajak seringkali terbentur dengan adanya tekanan untuk meningkatkan laba (Yin dan Cheng, 2004). Hal ini cenderung terjadi pada perusahaan terbuka. Bagi perusahaan yang labanya tidak mencapai target, penurunan laba untuk penghematan pajak sangat dihindari.

\section{SIMPULAN}

Berdasarkan hasil dan pembahasan yang dilakukan sebelumnya dapat diambil kesimpulan sebagai berikut :

a. Leverage berpengaruh positif signifikan terhadap penghindaran pajak. Hal ini menunjukkan bahwa terjadi hubungan searah antara Leverage dengan penghindaran pajak sehingga apabila terjadi kenaikan pada Leverage maka akan terjadi kenaikan pula pada penghindaran pajak.

b. Kompensasi rugi fiskal tidak berpengaruh signifikan terhadap penghindaran pajak.

c. Manajemen laba berpengaruh positif signifikan terhadap penghindaran pajak. Hal ini menujukkan bahwa bahwa terjadi hubungan searah antara Manajemen Laba dengan penghindaran pajak sehingga apabila terjadi kenaikan pada Manajemen Laba maka akan terjadi kenaikan pula pada penghindaran pajak. 
Berdasarkan penelitian yang dilakukan, terdapat keterbatasan penelitian sebagai berikut :

a. Sampel penelitian dibatasi hanya pada perusahaan sektor manufaktur yang terdaftar di Bursa Efek Indonesia.

b. Penelitian ini hanya menggunakan pengamatan terbatas selama tiga tahun, yaitu dari tahun 2013 hingga 2015.

\section{DAFTAR PUSTAKA}

Annisa, N.A. (2011). Pengaruh Corporate Governance Terhadap Tax Avoidance. Skripsi.

Assih, P., Gudono, M. (2000). Hubungan Tindakan Perataan Laba dengan Reaksi Pasar atas Pengumuman Informasi Laba Perusahaan yang Terdaftar Di Bursa Efek Jakarta. Simposium Nasional Akuntansi II.

Atmaja, L.S. (2008). Teori dan Praktik Manajemen Keuangan. Yogyakarta: CV

Atwood, T. J., Drake, M. S., Myers, J. N., \& Myers, L. A. (2012). Home country tax system characteristics and corporate tax avoidance: International evidence. Accounting Review. http://doi.org/10.2308/accr-50222

Choi, Y.R. (2003). Taxes and Corporate Capital Structure. Journal of Finance, 11(1).

Darmawan, I.G.H., Sukartha, I.M. (2014). Pengaruh Penerapan Corporate Governance, Leverage, Return On Assets, Dan Ukuran Perusahaan Pada Penghindaran Pajak. E-Jurnal Akuntansi Universitas Udayana. 9.1 (2014):143-161.

Dechow, P.M., Sloan, R.G., Sweeney, A.P. (1995). Detecting Earnings Management. The Accounting Review 70, 193-225.

Desai, M.A., Dhammapala, D. (2007a). Taxation and Corporate Governance : An Economic Framework. Dalam Working Paper Havard University, University of Connecticut and University of Michigan.

Desai, M.A., Dhammapala, D. (2007b). Earning Management and Corporate Tax Shelter.Dalam Working Paper Havard University, University of Connecticut and University of Michigan.

Dunbar et al. (2011) What do measures of tax aggresiveness measure? National Tax Association Proceedings from the 103rd Annual Conference in Chicago

Dyreng, S. D., Hanlon, M., \& Maydew, E. L. (2008). Long-run corporate tax avoidance. Accounting Review, 83(1), 61-82. http://doi.org/10.2308/accr.2008.83.1.61

Frank, M.M., Lynch, L.J, Rego, S.O. (2009).Tax Reporting Aggressiveness and Its Relation to Aggressive Financial Reporting. The Accounting Review: Vol. 84, No. 2, pp. 467-496. 
Ghozali, I. (2013). Aplikasi Analisis Multivariate dengan Program SPSS. Edisi ketujuh. Semarang: Badan Penerbit Universitas Diponegoro

Graham, J., and Tucker, A. (2006). Tax shelters and corporate debt policy. Journal of Financial Economics 81: 563-594.

Gujarati, D.N., Porter, D.C. (2009). Basic Econometrics,5th edition. McGraw-Hill

Gumanti, T.A. (2000). Earning Management: Suatu Telaah Pustaka. Jurnal Akuntansi dan Keuangan Vol. 2, No. 2, Nopember 2000: 104 - 115.

Handayani, R.(2009). Pengaruh Ukuran Perusahaan terhadap Manajemen Laba. Dalam Jurnal Bisnis dan Akuntansi, 11(1), :h:33-56. Program Magister Ilmu Akuntansi Universitas Diponegoro Semarang.

Hanlon, M., Heitzman, S. (2010). A review of tax research. Journal of Accounting and Economics, 50 (40). 127 - 178.

Healy, P. M. (1985). The Effect of Bonus Schemes On Accounting Decisions. Journal of Accounting and Economics 7:85-107.

Healy, P. M., Wahlen, J.M. (1998). A Review of Earnings Management Literature and its Implications For Standard Setting. Accounting Horizons: 365-383.

Hendriksen, E. S., Breda, M. (1992). Accounting Theory. 5th Edition. USA: Richard D Irwin Inc.

Jensen, M. C., Meckling, W.H. (1976). Theory of the Firm : Managerial Behavior, Agency Costs and Ownership Structure . Journal of Financial Economics,Oktober, 1976, V. 3, No. 4, pp. 305-360. Avalaible from: http://papers.ssrn.com

Jones, J. (1991). Earnings Management During Import Relief Investigations. Journal Of Accounting Research, Vol 29, No.2 1991, p.193 - 228.

Kieso, D. E., Jerry J. W., Warfield, T.P. (2011) Accounting Principles. $10^{\text {th }}$ Edition. Hoboken: John Wiley \& Sons, Inc

Kothari, S.P., Leone, A.J., \& Wasley, C.E. (2005). Performance Matched Discretionary Accrual Measures. Journal of Accounting and Economics, 39 (1), 163-197.

Kristanto, S.B. (2015). Dampak Praktek manajemen Laba terhadap Manajemen Pajak Perusahaan.

Manzon, G.B., Plesko, G.A. (2001). The Relation Between Financial And Tax Reporting Measures Of Income

Marfu'ah, L. (2015). Pengaruh Return on Assets, leverage, ukuran perusahaan, kompensasi rugi fiskal dan koneksi politik terhadap Tax Avoidance.

Maria, M.R., Tommy Kurniasih. 2013. Pengaruh Return on Assets, Leverage, Corporate Governance, dan Kompnsasi Laba Fiskal pada Tax Avoidance. Dalam Buletin Studi Ekonomi, 18(1), :h:58-66. Fakultas Ekonomi Universitas Udayana.

Mulyani, S. (2013). Pengaruh Karakteristik Perusahaan, Koneksi Politik Dan Reformasi Perpajakan Terhadap Penghindaran Pajak. E-Jurnal Akuntansi.

Ozkan, A. (2001). Determinants of Capital Structure and Adjustment to Long-run Target: Evidence from UK Company Panel Data. Journal of Business Finance and Accounting, 28: 175-199. 
Prakosa, K.B. (2014). Pengaruh Profitabilitas, Kepemilikan Keluarga, Dan Corporate Governance Terhadap Penghindaran Pajak Di Indonesia. Simposium Nasional Akuntansi 17 Mataram. Lombok.

Putri, L.T.Y. (2014). Pengaruh Likuiditas, Manajemen Laba Dan Corporate Governance Terhadap Agresivitas Pajak Perusahaan. Skripsi Program studi akuntansi Fakultas ekonomi Universitas negeri padang

Richardson, V.J. (1998). Information Asymmetry and Earnings Management: Some Evidence. Dissertation, University of Kansas, March.

Sari, D.K.(2010). Karakteristik Kepemilikan Perusahaan, Corporate Governance, dan Tindakan Pajak Agresif. Tesis Program Studi Ilmu Akuntansi Fakultas Ekonomi Universitas Indonesia, Depok.

Sari, K.S., dan Martani, D. (2010). Ownership Characteristic, Corporate Governance, and Tax Aggressiveness. The 3rd Accounting and The 2nd Colloquium.

Scott, William, R. 2015. Financial Accounting Theory, 7th Edition, New Jersey: Prentice-Hall, Inc.

Supramono, K.D.S. (2012). Liquiditas, Leverage, Komisaris Bebas dan Manajemen Laba Terhadap Agresivitas Pajak Perusahaan. Jurnal Keuangan dan Perbankan, Vol.16, No.2 Mei 2012, hlm. 167-177

Tiaras, I., Wijaya, H. (2015). Pengaruh Likuiditas, Leverage, Manajemen Laba, Komisaris Bebas dan Ukuran Perusahaan Terhadap Agresivitas Pajak. Jurnal Akuntansi, Vol XIX No.3, September 2015: 308-397

Undang-Undang Nomor 11 Tahun 2016 tentang pengampunan Pajak

Waluyo, T.M., Basri, Y.M., Rusli. (2015). Pengaruh Return on Asset, Leverage, Ukuran Perusahaan, Kompensasi Rugi Fiskal dan Kepemilikan Institusi Terhadap Penghindaran Pajak 